The University of Maine

DigitalCommons@UMaine

Earth Science Faculty Scholarship

Earth Sciences

9-1-2004

\title{
Variations in Ice Rafted Detritus on Beaches in the South Shetland Islands: A Possible Climate Proxy
}

Brenda L. Hall

University of Maine - Main, brendah@maine.edu

Ethan R. Perry

Follow this and additional works at: https://digitalcommons.library.umaine.edu/ers_facpub

Part of the Earth Sciences Commons

\section{Repository Citation}

Hall, Brenda L. and Perry, Ethan R., "Variations in Ice Rafted Detritus on Beaches in the South Shetland Islands: A Possible Climate Proxy" (2004). Earth Science Faculty Scholarship. 117.

https://digitalcommons.library.umaine.edu/ers_facpub/117 


\title{
Variations in ice rafted detritus on beaches in the South Shetland Islands: a possible climate proxy
}

\author{
BRENDA L. HALL ${ }^{1,2}$ and ETHAN R. PERRY ${ }^{2}$ \\ ${ }^{1}$ The Climate Change Institute, University of Maine, Orono, ME 04469, USA \\ ${ }^{2}$ Department of Earth Sciences' University of Maine, Orono, ME 04469, USA
}

\begin{abstract}
Raised beach ridges on Livingston Island of the South Shetland Islands display variations in both quantity and source of ice rafted detritus (IRD) received over time. Whereas the modern beach exhibits little IRD, all of which is of local origin, the next highest beach $\left(\sim 250{ }^{14} \mathrm{C}\right.$ yr $\left.\mathrm{BP}\right)$ has large amounts, some of which comes from as far away as the Antarctic Peninsula. Significant quantities of IRD also were deposited $\sim 1750$ ${ }^{14} \mathrm{C}$ yr BP. Both time periods coincide with generally cooler regional conditions and, at least in the case of the $\sim 250 \mathrm{yr}$ old beach, local glacial advance. We suggest that the increases in ice rafting may reflect periods of greater glacial activity, altered ocean circulation, and/or greater iceberg preservation during the late Holocene. Limited IRD and lack of far-travelled erratics on the modern beach are both consistent with the ongoing warming trend in the Antarctic Peninsula region.
\end{abstract}

Received 26 November 2003, accepted 16 June 2004

Key words: Antarctica, Holocene, ice rafting, Livingston Island

\section{Introduction}

The geographic extent, timing, and, ultimately, origin of Holocene climate variations remain intriguing problems in global change research. Although not as large as fluctuations during the late-glacial period, these climate oscillations nonetheless are important for addressing the causes of abrupt change (Bond et al. 1997).

The Holocene climate record of Antarctica is ambiguous, due largely to a lack of geographic and time resolution, inadequate dating, and limited exposures. Ingólfsson et al. (1998) produced a synthesis of available data that suggested possible mid-Holocene readvance, warmer conditions $\sim 3000-4000$ yr BP, and late Holocene cooling. But not all data show this pattern. The search for a Little Ice Age-type event illustrates the disparity among Antarctic Holocene climate records. Glaciers in the South Shetland Islands, for example, are believed to have undergone advance during this time period (AD 1260-1860; Birkenmajer 1981, Clapperton \& Sugden 1988, Martínez de Pisón et al. 1996, Björck et al. 1996). The South Pole ice core also seems to show cooling, but Siple Station records suggest warmer and less dusty conditions (Mosley-Thompson et al. 1990, Mosley-Thompson 1992). The Siple Dome glaciochemical record shows an abrupt onset of stormier conditions at $\sim$ AD 1400, interpreted as enhanced atmospheric circulation (Kreutz et al. 1997). One possibility is that there is a variety of regional responses to a single forcing event.

Here we present a new record of Holocene ice rafting changes in the South Shetland Islands (Fig. 1) that has potential as a climate proxy. This record was derived from raised beach ridges on Byers Peninsula of Livingston Island. During the course of field work, we observed that sediments within the beaches consist of stratified sand and gravel with only rare larger clasts. However, boulders are present on all beach surfaces to varying degrees. We interpret these boulders as predominantly ice rafted detritus (IRD; see Results and Discussion for more detail). We examined IRD on a flight of six raised beaches that spans a time period of approximately 4000 years. In order to quantify variations in IRD, every boulder along each beach crest was counted in standard transects approximately $30 \mathrm{~m}$ wide. We also noted boulder lithology. Beach transects ranged from 0.74 to $2.1 \mathrm{~km}$ in length. Care was taken to analyse the same segment of coastline for each beach, so that variations in aspect would not influence the results. The number of boulders divided by the transect lengths yielded averages in boulders per metre that were compared among beaches.

\section{Results}

We concentrated on South Beaches $\left(62^{\circ} 40^{\prime} \mathrm{S}, 61^{\circ} 04^{\prime} \mathrm{W}\right)$, located on the south coast of Byers Peninsula, facing Deception Island and the Antarctic Peninsula (Fig. 1). As first noted by López-Martínez et al. (1996a), there are six major beach ridges at the site examined, ranging from $2 \mathrm{~m}$ (modern beach) to $15 \mathrm{~m}$ elevation above mean sea level (Fig. 2). Beaches extend continuously for several kilometres. They are broad-crested and range from $2-4 \mathrm{~m}$ in height. Some have a prominent back slope. Examination of beach sediments revealed that they consist of generally stratified sand and gravel. Large clasts are rare within the beaches. Yet boulders (average size $=\sim 30 \mathrm{~cm}$ diameter, rarely as large as $\sim 50 \mathrm{~cm}$ ) are present on all the surfaces - very common on some beaches, but rare on others. These boulders tend to cluster near the front of the beaches, 


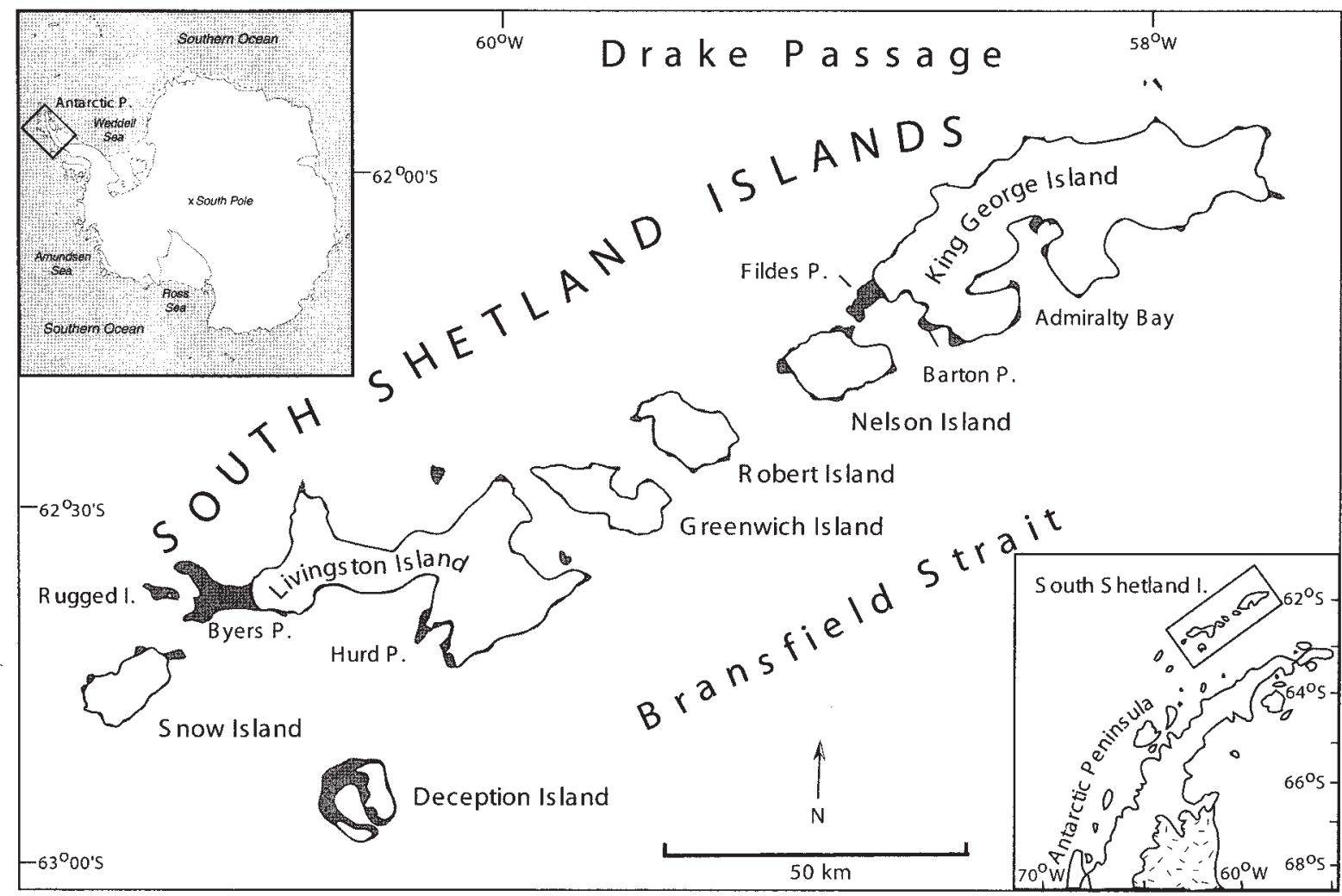

Fig. 1. Index map of the South Shetland Islands.

although they also are present over the entire crests. Because they contain lithologies exotic to local bedrock or till, we interpret the boulders as IRD, probably brought in at high tide by iceberg remnants.

Table I gives the number of boulders per metre of transect on the analysed beaches. These data support the field observation that some beaches display much more IRD than others. There is an order-of-magnitude variation, with Beaches 2 and 4 exhibiting significantly higher amounts. The difference is particularly striking between Beaches 4

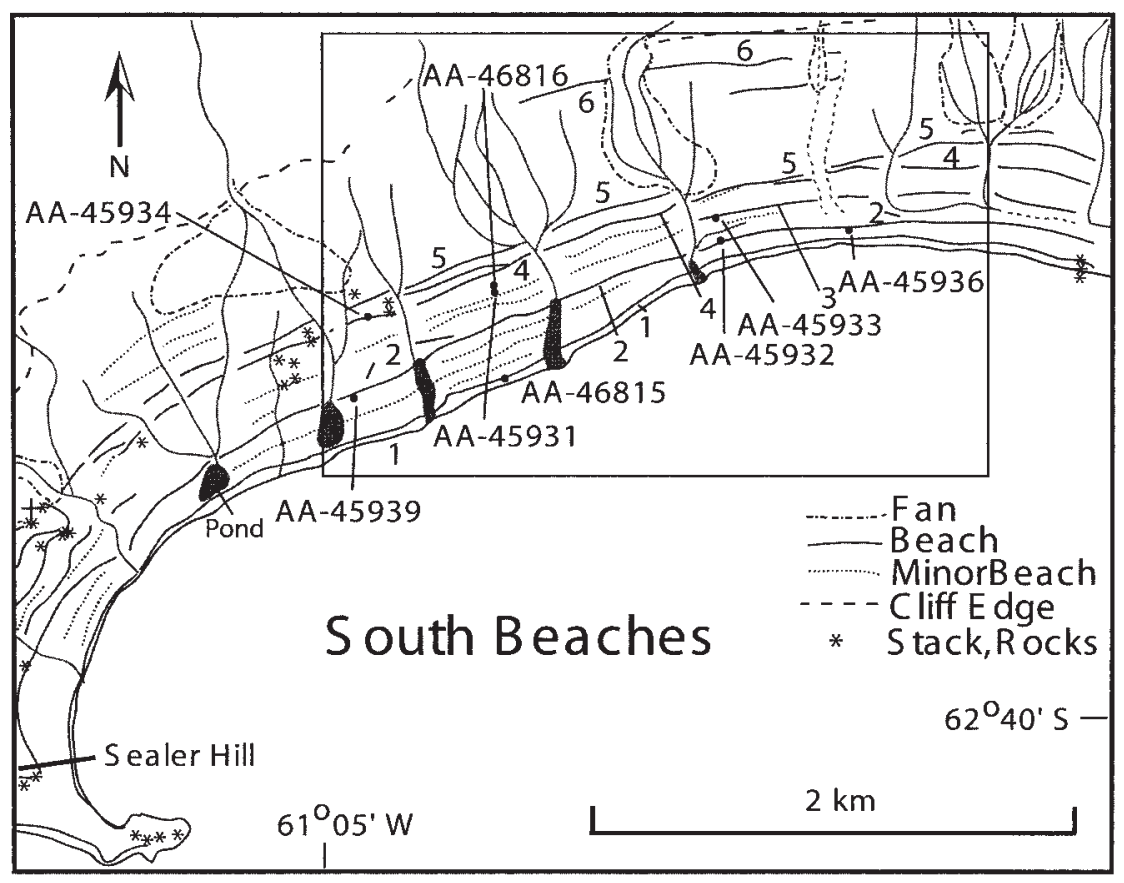

Fig. 2. Generalized map of South Beaches, Byers Peninsula. Numbers

(1-6) correspond to beach names in text. The box indicates the approximate area where the boulder-counting study took place. The figure is simplified from our surficial map that was created from aerial photographs and then checked in the field. Not all features are shown. Well-developed beaches are shown as solid lines. Dashed lines mark the location of indistinct or discontinuous beach crests. We did not count boulders from beaches shown as dashed lines. 
Table I. Boulders counted on beach surfaces in standard $\sim 30 \mathrm{~m}$ wide swaths

\begin{tabular}{|c|c|c|c|c|c|c|}
\hline Beach & $\begin{array}{l}\text { Length } \\
\text { studied }\end{array}$ & $\begin{array}{l}\text { Total no. } \\
\text { of boulders b }\end{array}$ & $\begin{array}{l}\text { Total } \\
\text { oulders } \mathrm{m}^{-1}\end{array}$ & $\begin{array}{c}\text { Granite } \\
\text { boulders }\end{array}$ & $\begin{array}{l}\text { Granite } \\
\text { boulders } \mathrm{m}^{-1}(\end{array}$ & $\begin{array}{c}\text { Age } \\
\left({ }^{14} \mathrm{C} \text { yr BP }\right)\end{array}$ \\
\hline 1 & $1500 \mathrm{~m}$ & 28 & 0.019 & 0 & 0.0 & Modern \\
\hline 2 & $2175 \mathrm{~m}$ & 791 & 0.364 & 46 & 0.021 & $\sim 250$ \\
\hline 3 & $740 \mathrm{~m}$ & 10 & 0.014 & 2 & 0.003 & $\sim 360$ \\
\hline 4 & $2050 \mathrm{~m}$ & 803 & 0.392 & 38 & 0.019 & $\sim 1750$ \\
\hline 5 & $1550 \mathrm{~m}$ & 40 & 0.026 & 1 & 0.0006 & No data \\
\hline 6 & $875 \mathrm{~m}$ & 15 & 0.017 & 1 & 0.001 & No data \\
\hline
\end{tabular}

Note: Given the small number of boulders on some beaches, minor differences in IRD among beaches are not likely to be statistically significant. Instead, we want to illustrate the fact that some beaches ( $2 \& 4)$ contain a lot more IRD than others, not only in total amount of boulders, but also in total amount of far-travelled granite erratics. Other boulders noted consisted of primarily fine-grained igneous rocks (e.g. basalts, breccias) derived locally from bedrock or till. Some marine mudstones were noted on the beaches, but they did not attain boulder size. These also were derived locally. See López-Martínez et al. (1996b) for a summary of the bedrock of Byers Peninsula.

and 5, which are contiguous in most places and are similar in size, slope, and form.

Not only are there variations in the amounts of ice rafted boulders among beaches, but there also are changes in the sources of the debris (Table I). Most clasts come from local volcanic rocks. However, some have exotic lithologies. Although exact percentages are meaningless because of the small sample size in some cases, most beaches display a small number of white granodiorite rocks. These rocks may come from farther east in the South Shetland Islands, or they may be from the Antarctic Peninsula. They are not local to Byers Peninsula, and we did not find any such clasts on the modern beach, despite examining more than $1.5 \mathrm{~km}$ of coastline. Another important lithology is the pink biotite-hornblende phaneritic granite found only on Beach 2. This rock is not known to crop out in the South Shetland Islands, nor did we find this rock type on any other beach along the entire southern coast of Byers Peninsula. Additional pink granite boulders occur on Beach 2 farther east on Byers Peninsula, outside of the area counted.

\section{Discussion}

We believe that the boulders on the beach surfaces are predominantly ice rafted. Other options include direct deposition by glacier ice, winnowing or reworking of beach sediment to form a lag deposit, or sea ice push of local boulders. The beach segments analysed are distant $(\sim 5 \mathrm{~km})$ from any present ice margin, and thus direct glacial deposition is unlikely. The boulders cannot be a lag, because such clasts are rare or even absent within the beaches. In addition, the boulders do not form the tight, densely packed, striated and smoothed pavements noted by Hansom (1983) to occur among some beach ridges and thought to relate to sea ice push and compaction. Sea ice push alone cannot account for the fact that some rocks are of exotic origin.
Examination of the number of exotic clasts per metre of transect reveals the same pattern seen in overall boulder distribution (Table I). Thus, we favour the hypothesis that the material is predominantly ice rafted, brought to South Beaches by iceberg remnants.

The source of the exotic boulders is uncertain. Diorite crops out $30 \mathrm{~km}$ to the east. It is possible that some of the grey coloured granodiorite boulders may belong to the diorite unit. However, the source for the pink, potassium-feldspar rich, biotite-hornblende granite boulders on Beach 2 is not known to occur in the South Shetland Islands. These rocks probably were ice rafted from the Antarctic Peninsula, where bedrock of similar composition is known to exist (see Scarrow et al. 1997). Arche et al. (1996) reached the same conclusion for similar rocks on Holocene beaches on western Byers Peninsula, as well as on some of the older raised marine platforms.

We suggest that changes in quantity and source of IRD on Byers Peninsula beaches reflect variations in ice rafting conditions in the region. The greatest concentrations of IRD occur on Beaches 2 and 4. These beaches also have fartravelled clasts. Significantly lesser amounts of debris were rafted to Byers Peninsula during the formation of Beaches 3,5 , and 6 . Very little occurs on the modern beach, and all is of local origin. This suggests that ice rafting has been greater at times in the past than it is now. Sample size precludes us from detecting statistically significant variations among beaches with low IRD concentrations. Instead, our goal is to illustrate the clear difference between those beaches with very high amounts of IRD and those with very little.

Variations in IRD likely reflect environmental change. Cold periods with increased glacial activity and iceberg preservation would favour large amounts of IRD. Changes in regional ocean circulation and temperature also could lead to greater or fewer numbers of icebergs reaching the South Shetland Islands from the Antarctic Peninsula.

One could argue that increases in IRD actually reflect times of low sea ice when icebergs could reach Byers Peninsula more easily. We think this unlikely for two reasons. First, although some parts of the South Shetland Islands experience winter sea ice, there is not significant sea ice offshore of South Beaches today. It is possible to land an inflatable boat at the shore, year round, during most years. Yet, IRD is scarce on the modern beach despite the lack of a sea ice barrier. That, coupled with the fact that iceberg preservation may be less likely during times of reduced sea ice, leads us to suggest that increases in IRD at South Beaches are due to enhanced glacier activity, possibly coupled with cooler ocean temperatures and/or altered ocean currents.

Although we favour environmental change, there are other potential reasons for the changes in IRD concentration seen on South Beaches. For instance, variations in beach aspect with relation to wind and ocean currents could cause 
Table II. Radiocarbon dates, South Beaches

\begin{tabular}{lcccclc}
\hline Beach & $\begin{array}{c}\text { Sample } \\
\text { number }\end{array}$ & $\begin{array}{c}\text { Age } \\
\left({ }^{14} \mathrm{C} \text { yr BP }\right)\end{array}$ & $\begin{array}{c}\text { Age (corrected) } \\
\left({ }^{14} \mathrm{C} \text { yr BP }\right)\end{array}$ & $\begin{array}{c}\text { Elevation } \\
(\mathrm{m})\end{array}$ & Description & Reference \\
\hline 1 & AA-46815 & $1271 \pm 47$ & 0 & 2 & Whale vertebra on modern storm beach & This paper \\
2 & AA-45939 & $1431 \pm 44$ & $131 \pm 44$ & 4 & Whale vertebra partially buried in beach foreslope & This paper \\
2 & AA-45936 & $1545 \pm 46$ & $245 \pm 46$ & 4 & Whale vertebra partially buried in beach foreslope & This paper \\
2 & AA-45932 & $1625 \pm 42$ & $325 \pm 42$ & 5 & Bone buried in beach foreslope & This paper \\
3 & AA-46816 & $1572 \pm 42$ & $272 \pm 42$ & 6 & Whalebone partially buried in beach surface & This paper \\
3 & AA-45931 & $1692 \pm 42$ & $392 \pm 42$ & 6 & Whalebone partially buried in beach; condition poorer than other samples This paper \\
3 & AA-45933 & $1715 \pm 42$ & $415 \pm 42$ & 4 & Whalebone buried in beach foreslope & Curl 1980 \\
$-*$ & I-7870 & $2530 \pm 85$ & $1230 \pm 85$ & 7.6 & Whalebone on(?) crest of beach & This paper \\
4 & AA-45934 & $3115 \pm 47$ & $1815 \pm 47$ & 9 & Whalebone buried in beach crest & Hansom 1979 \\
$4 ?$ & SRR-1086 & $2823 \pm 40$ & $1523 \pm 40$ & 10.3 & Whalebone buried in beach & Hansom 1979 \\
$4 ?$ & SRR-1087 & $3121 \pm 25$ & $1821 \pm 25$ & 10.1 & Whalebone buried in beach & \\
\hline
\end{tabular}

Note: All samples are of collagen. *Possibly from small ridge in between beaches 3 and 4 . Exact locations and beaches for previously published data are unknown. All samples from this study were measured from mean sea level. Some previously published dates are not included in this table (from Curl 1980 , and Sugden \& John 1973), because they yield post-modern ages when corrected by 1300 years and may be contaminated with bomb carbon. None of the samples from this study shows any evidence of butchering associated with whaling. They lack cut or burn marks and are not part of bone groupings that sometimes characterize butchering sites.

spatial changes in IRD distribution. To eliminate the effect of such spatial variations, all analysed beaches are from the same segment of coastline, have the same aspect, and have unrestricted access to the sea.

All things being equal, one might expect the amount of IRD to decrease through time, because of the shallowing trend due to land uplift. Shallow water offshore might prevent icebergs from arriving at the beaches as freely as when the water was deep. This would lead to the older (higher) beaches having more IRD than those at lower elevation. However, our data do not show this decreasing trend through time, indicating that the IRD variations are not due to shallowing coastal waters.

Variations in land uplift also could affect IRD concentration if some beaches remained close to sea level for extended periods of time before being elevated. In general, rates of uplift in a region experiencing glacioisostatic rebound should be greatest immediately following deglaciation and decrease thereafter. In this case, lower beaches would have greater amounts of time to accumulate IRD than higher elevation beaches. This might explain the near-lack of IRD on the uppermost beach. However, it does not account for the near lack of IRD on the modern beach, nor the stark contrast in IRD between Beaches 4 and 5 . Moreover, it does not explain changes in the source of IRD. In summary, it seems as if the simplest explanation is that the changes in IRD relate to environmental change in the South Shetland Islands.

Chronology is the key for putting ice rafting variations into a regional context. In general, beaches in the South Shetland Islands are poorly dated. However, South Beaches has the best-dated record in the region (Table II). The modern beach yielded an age of $0{ }^{14} \mathrm{C}$ yr BP (relative to $\mathrm{AD}$ 1950), when corrected for the marine reservoir effect (1300 yrs, all dates cited in text are corrected for the marine reservoir effect - see below). Other samples from the same beach yielded ages likely contaminated with bomb carbon (i.e. Curl 1980) and are not listed in Table II. Beach 2 yielded whalebone dating between $131 \pm 44$ and $325 \pm 42$ ${ }^{14} \mathrm{C}$ yr BP (average of $\sim 250{ }^{14} \mathrm{C}$ yr BP). Beach 3 produced three samples, ranging from $272 \pm 42$ to $415 \pm 42{ }^{14} \mathrm{C} \mathrm{yr} \mathrm{BP}$ (average of $360{ }^{14} \mathrm{C}$ yr BP) Part of this range may be due to the fact that Beach 3 splits into several ridges west of our study area and may be of multiple ages. Whalebone buried in gravel in Beach 4 yielded an age of $1815 \pm 47{ }^{14} \mathrm{C}$ yr BP Two previous dates of $1523 \pm 40$ and $1821 \pm 25$ (Hansom 1979) may also be of whalebone from this beach. If so, the average of the three dates yields an age of $\sim 1750{ }^{14} \mathrm{C}$ yr BP. The upper beaches remain undated. The highest beach may be about $4200{ }^{14} \mathrm{C}$ yr BP, based on other relative sea-level data from the region (Barsch \& Mäusbacher 1986).

All dates in this paper have been corrected for a marinereservoir effect of 1300 years, based on dates of historical specimens (Björck et al. 1991a, Berkman \& Forman 1996, Hall \& Baroni, unpublished data). We present two additional dates of whalebone to aid in calculating the reservoir correction. These samples are both from animals killed during whaling, as evidenced by cut marks on the bones. Both samples are from King George Island and yield ages of $1410 \pm 43(\mathrm{AA}-46814)$ and $1450 \pm 47$ (AA-46813) ${ }^{14} \mathrm{C}$ yr BP. The earliest sealers and whalers reached the South Shetland Islands $\sim$ AD 1820. According to Curl (1980), use of factory ships after AD 1910 led to the total consumption of the whale carcass. Therefore, death of these whales must postdate AD 1820 and likely predates AD 1910. Splitting the difference yields a time of death at $\sim \mathrm{AD} 1865$ and a marine reservoir correction of $1325-1365{ }^{14} \mathrm{C}$ yr BP, similar to that obtained from other species (i.e. 1300 years, Berkman \& Forman 1996). Using a correction of 1300 years, increases in ice rafting occurred at $\sim 250$ (Beach 2) and $\sim 1750{ }^{14} \mathrm{C} \mathrm{yr}$ BP (Beach 4), with lesser amounts during formation of Beaches 3, 5, and 6, and at present. 


\section{A potential climate proxy}

We suggest that variation in IRD through time on raised beaches has potential as a climate proxy in the northern Antarctic Peninsula region. Ideally, we would test this hypothesis by examining numerous, widespread sites to check the regional applicability of our South Beach dataset. As that is not currently possible, we look to independent evidence for heightened ice rafting activity during the late Holocene in the region.

Comparison between the South Beaches data and regional climate records suggests some broad similarities, as IRD on Byers Peninsula increases concordantly with general climate deterioration in the late Holocene. The record from South Beaches can be summarized as follows:

i) generally minor amounts of IRD in the mid-Holocene,

ii) a sharp increase in IRD at $\sim 1750{ }^{14} \mathrm{C}$ yr BP,

iii) slightly lesser amounts of IRD during deposition of Beach 3 at $\sim 360{ }^{14} \mathrm{C}$ yr BP,

iv) an increase in amount of IRD and number of fartravelled erratics at $\sim 250{ }^{14} \mathrm{C}$ yr BP, and

v) only minor amounts of IRD on the modern beach, all of which examined was from local sources.

At several locations in the island chain, alpine glaciers experienced multiple advances during the past several hundred years. Radiocarbon dates of beaches overrun during the advances, as well as lichenometric ages of the moraines themselves, indicate widespread glacier expansion dating to the 1700 s and early 1800 s (Curl 1980, Birkenmajer 1981, Hjort et al. 2003). This timing corresponds well with the age of Beach 2 and suggests that glacier expansion in the South Shetland Islands may have contributed in part to the increases in IRD seen at South Beaches.

Other evidence of late Holocene climate change comes from Byers Peninsula lake sediments. Following a midHolocene climate optimum, Midge Lake records a gradually deteriorating environment with both warm and cold pulses (Björck et al. 1991b). One warm event occurred at $\sim 2000 \mathrm{yr} \mathrm{BP}$, and generally colder than present conditions existed between $\sim 1500$ and $\sim 500$ yr BP. Nearby Lake Åsa shows a distinct climate deterioration with cold, dry conditions starting $\sim 2500 \mathrm{yr}$ BP and continuing until close to the present day (Björck et al. 1993). A similar history comes from the Bransfield Strait where Yoon et al. (2003), based on analysis of diatom ooze in sediment cores, suggested that sea ice became more pervasive $\sim 2500$ years ago.

Farther away on the Antarctic Peninsula, sediments from Lallemand Fjord show evidence of several late Holocene climate fluctuations (Shevenell et al. 1996). Detailed comparisons with our record are difficult because the fjord chronology relies on only one radiocarbon date $\left(\sim 8000{ }^{14} \mathrm{C}\right.$ yr BP) and an assumed constant sedimentation rate. However, similar to the lake records on Byers Peninsula, the fjord record also shows a deteriorating climate after about $2500{ }^{14} \mathrm{C}$ yr BP, with cold periods between $\sim 2500-1600{ }^{14} \mathrm{C}$ yr BP and during the last 1000 years. In fact, the Müller Ice Shelf is thought to have advanced in the fjord beginning about 400 years ago (Domack et al. 1995). Climate deterioration over the past several thousand years also is supported by productivity changes in the Palmer Deep (Leventer et al. 1996, Domack et al. 2001). A gravel abundance diagram, a proxy for IRD, shows several pronounced peaks, indicating times of increased ice rafting. One of these peaks, centred at $\sim 1625$ cal yr BP, may correspond with the evidence for increased ice rafting at South Beaches at $\sim 1750{ }^{14} \mathrm{C}$ yr BP $(1630-1692 \mathrm{cal}$ yr BP). Domack et al. (2001) also recognized a Little Ice Age cool event in the Palmer Deep, beginning at $\sim 700 \mathrm{cal}$ yr BP. Overall, marine records from the western Antarctic Peninsula suggest a warm middle Holocene and a Neoglacial beginning $3.2 \mathrm{ka}$ and include a Little Ice Age (Domack et al. 2003).

If one accepts that variations in IRD on raised beaches follow other climate proxies in the region, then the South Shetland Islands data may also show evidence of the warming trend taking place on the Antarctic Peninsula over the past century (Vaughan \& Doake 1996). If the quantity and source of IRD at South Beaches reflect glacier activity, preservation of icebergs, and ultimately temperature, then the modern beach records the warmest conditions over at least the last 1750 years.

In conclusion, ice rafting records from raised beaches on Livingston Island have the potential to be used as a proxy for environmental change in the South Shetland Islands, although much more work needs to be done to determine the regional applicability of these data. The South Beaches record indicates increased amounts of IRD at $\sim 250{ }^{14} \mathrm{C}$ yr BP and $\sim 1750{ }^{14} \mathrm{C}$ yr BP, both of which broadly correspond to times of climate deterioration and/or glacial advance in the South Shetland Islands and northern Antarctic Peninsula region. The boulder-counting method used here should be applicable to other sites. It will work best where the beaches are otherwise fine-grained and the possibility of other methods of boulder transport can be eliminated. We suggest that increases in IRD reflect greater iceberg preservation and enhanced glacier activity. Although this interpretation is generally supported by other regional proxy data, we cannot yet rule out altered ocean circulation as a cause for IRD variations. More data covering a wider geographic area would help to address this issue.

\section{Acknowledgements}

We would like to thank Captain Warren Sanamo, the crew, and the support staff of the Laurence M. Gould for their logistical support in the South Shetland Islands. A. Roy 
analysed the composition of erratics. The Chilean Air Force provided helicopter transport near Frei Base. K. Kreutz made several helpful comments on the manuscript. We especially thanks J. Evans for logistical support well beyond the call of duty. Comments by J. López-Martínez, A. Vaughan, and an anonymous reviewer greatly improved the paper. This research was supported by the Office of Polar Programs of the National Science Foundation.

\section{References}

Arche, A., López-Martínez, J., Serrano, J. \& Martínez de Pisón, E. 1996. Marine landforms and deposits. In LÓPEZ-MARTínEZ, J., Thomson, M.R.A. \& Thomson, J.W., eds. Geomorphological map of Byers Peninsula, Livingston Island. BAS GEOMAP series, sheet 5-a, 1:25 000, with supplementary text. Cambridge: British Antarctic Survey, $35-42$.

BARSCH, D. \& MäUSBACHER, R. 1986. Beiträge zur Vergletscherungsgeschichte und zur Reliefentwicklung der Südshetland Inseln. Zeitschrift für Geomorphologie, 61, 25-37.

Berkman, P.A. \& Forman, S.L. 1996. Pre-bomb radiocarbon and the reservoir correction for calcareous marine species in the Southern Ocean. Geophysical Research Letters, 23, 363-365.

BIRKENMAJER, K. 1981. Raised marine features and glacial history in the vicinity of $\mathrm{H}$. Arctowski station, King George Island (South Shetland Islands, West Antarctica). Bulletin de l'Academie Polonaise des Sciences, 29, 109-117.

Björck, S., HÅkansson, H., Olsson, S., Barnekow, L. \& Jansens, J. 1993. Paleoclimatic studies in the South Shetland Islands, Antarctica, based on numerous stratigraphic variables in lake sediments. Journal of Paleolimnology, 8, 233-272.

Björck, S., Håkansson, H., Zale, R., Karlén, W. \& Jönsson, B.L. 1991b. A late Holocene lake sediment sequence from Livingston Island, South Shetland Islands, with paleoclimatic implications. Antarctic Science, 3, 61-72.

Björck, S., HJort, C., Ingólfsson, Ó. \& Skog, G. 1991a. Radiocarbon dates from the Antarctic Peninsula region - problems and potential. Quaternary Proceedings, 1, 55-65.

Björck, S., HJort, C., Ingólfsson, Ó., Zale, R. \& Ising, J. 1996. Holocene glacial chronology from lake sediments. In LÓPEZ-MARTÍNEZ, J., Thomson, M.R.A. \& Thomson, J.W., eds. Geomorphological map of Byers Peninsula, Livingston Island. BAS GEOMAP series, sheet 5-a, 1:25 000, with supplementary text. Cambridge: British Antarctic Survey, 49-51.

Bond, G., Showers, W., Cheseby, M., Lotti, R., Almasi, P., DeMenocal, P., Priori, P., Cullen, H., Hajdas, I. \& Bonani, G. 1997. A pervasive millennial-scale climate cycle in the North Atlantic: the Holocene and late-glacial record. Science, 278, 1257-1266.

Clapperton, C.M. \& Sugden, D.E. 1988. Holocene glacier fluctuations in South America and Antarctica. Quaternary Science Reviews, 7, 185-198.

CuRL, J.E. 1980. A glacial history of the South Shetland Islands, Antarctica. Ohio State University, Institute of Polar Studies Report, No. 63, $129 \mathrm{pp}$.

Domack, E.W., Leventer, A., Root, S., Ring, J., Williams, E., Carlson, D., Hirshorn, E., Wright, W., Gilbert, R. \& Burr, G. 2003. Marine sedimentary record of natural environmental variability and recent warming in the Antarctic Peninsula. Antarctic Research Series, 79, 205-224.

Domack, E.W., Leventer, A., Dunbar, R., Taylor, F., Brachfield, S.F., SJunNESKÖG, S. \& ODP Leg 178 Scientific Party. 2001. Chronology of the Palmer Deep Site, Antarctic Peninsula: a Holocene paleoenvironmental reference for the circum-Antarctic. The Holocene, $11,1-9$.
Domack, E.W., Ishman, S.E., Stein, A.B., McClennan, C.E. \& Jull, A.S.T. 1995. Late Holocene advance of the Muller Ice Shelf, Antarctic Peninsula: sedimentological, geochemical, and palaeontological evidence. Antarctic Science, 7, 159-170.

HANSOM, J.D. 1979. Radiocarbon dating of a raised beach at $10 \mathrm{~m}$ in the South Shetland Islands, Antarctica. Marine Geology, 53, 211-229.

HANSOM, J.D. 1983. Ice-formed intertidal boulder pavements in the subAntarctic. Journal of Sedimentary Petrology, 53, 135-145.

Huort, C., Ingólfsson, Ó., Bentley, M.J. \& BJörCK, S. 2003. The Late Pleistocene and Holocene glacial and climate history of the Antarctic Peninsula region as documented by the land and lake sediment records a review. Antarctic Research Series, 79, 95-102.

Ingólfsson, Ó., Huort, C., Berkman, P.A., Buörck, S., Colhoun, E., Goodwin, I.D., Hall, B., Hirakawa, K., Melles, M., Möller, P. \& Prentice, M.L. 1998. Antarctic glacial history since the Last Glacial Maximum: an overview of the record on land. Antarctic Science, 10, 326-344.

Kreutz, K.J., Mayewski, P.A., Meeker, L.D., Twickler, M.S., Whitlow, S.I. \& Pittalwala, I.I. 1997. Bipolar changes in atmospheric circulation during the Little Ice Age. Science, 277, 1294-1296.

Leventer, A., Domack, E.W., Ishman, S.E., Brachfeld, S., McClennan, C.E. \& Manley, P. 1996. Productivity cycles of 200-300 years in the Antarctic Peninsula region: understanding linkages among the sun, atmosphere, oceans, sea ice, and biota. Geological Society of America Bulletin, 108, 1626-1644.

López-Martínez, J., Martínez de Pisón, E., Serrano, E. \& Arche, A. 1996a. Geomorphological map of Byers Peninsula, Livingston Island. In López-Martínez, J., Thomson, M.R.A. \& Thomson, J.W., eds. Geomorphological map of Byers Peninsula, Livingston Island. BAS GEOMAP series, sheet 5-a, 1:25 000, with supplementary text. Cambridge: British Antarctic Survey, 65 pp.

López-Martínez, J., Hathway, B., Lomas, S., Martínez de Pisón, E. \& ARCHE, A. 1996b. Structural geomorphology and geological setting. In López-Martínez, J., Thomson, M.R.A. \& ThOmson, J.W., eds. Geomorphological map of Byers Peninsula, Livingston Island. BAS GEOMAP series, sheet 5-a, 1:25 000, with supplementary text. Cambridge: British Antarctic Survey, 9-14.

Martínez de Pisón, E., Serrano, E., Arche, A. \& López-Martínez, J. 1996. Glacial geomorphology. In López-MARTínEZ, J., THOMSON, M.R.A. \& Thomson, J.W., eds. Geomorphological map of Byers Peninsula, Livingston Island. BAS GEOMAP series, sheet 5-a, 1:25000, with supplementary text. Cambridge: British Antarctic Survey, 23-27.

Mosley-Thompson, E. 1992. Paleoenvironmental conditions in Antarctica since AD 1500: ice core evidence. In BRADLEY, R.S. \& JONES, P.D., eds. Climate since $A D$ 1500. New York: Routledge, 572-591.

Mosley-Thompson, E., Thompson, L.G., Grootes, P.M. \& GundestruP, N. 1990. Little Ice Age (Neoglacial) paleoenvironmental conditions at Siple Station, Antarctica. Annals of Glaciology, 14, 199-204.

Scarrow, J.H., Vaughan, A.P.M. \& Leat, P.T. 1997. Ridge-trench collision-induced switching of arc tectonics and magma sources: clues from Antarctic Peninsula mafic dykes. Terra Nova, 9, 255-259.

Shevenell, A.E., Domack, E.W. \& Kernan, G.M. 1996. Record of Holocene paleoclimate change along the Antarctic Peninsula: Evidence from glacial marine sediments, Lallemand Fjord. Papers and Proceedings of the Royal Society of Tasmania, 130(2), 55-64.

Sugden, D.E. \& John, B.S. 1973. The ages of glacier fluctuations in the South Shetland Islands, Antarctica. In VAN Zinderen BAKKER, E.M., ed. The Palaeoecology of Africa, the surrounding islands, and Antarctica, vol, 8. Cape Town, South Africa: A.A. Balkema, 139-159.

VAughan, D.G. \& DoAKE, C.S.M. 1996. Recent atmospheric warming and retreat of ice shelves on the Antarctic Peninsula. Nature, 379, 328-331.

Yoon, H.I., PARK, B.K., KIM, Y., KANG, C.Y \& Kang, S.H. 2003. Origins and paleoceanographic significance of layered diatom ooze interval from the Bransfield Strait in the northern Antarctic Peninsula around 2500 yrs BP. Antarctic Research Series, 79, 225-238. 